\title{
Leucocyte ascorbic acid levels after acute myocardial infarction
}

\author{
R. Hume, E. Weyers, T. Rowan, D. S. Reid, and W. S. Hillis \\ From the Department of Medicine, Southern General Hospital, Glasgow
}

Leucocyte ascorbic acid was measured in 31 patients who had sustained an acute myocardial infarction. Nine of the patients were seen within 6 hours of the infarction and 22 patients within 12 hours. It was found that there was a significant fall in the leucocyte ascorbic acid to scorbutic levels within 12 hours of the infarction in each case, and this occurred when the white blood cell count was at its maximum. The fall also coincided with the peak plasma cortisol level. The level remained less than normal for the next two weeks and the reduction in leucocyte ascorbic acid at two weeks was related to the size of the myocardial infarction as reflected by the serum aspartate aminotransferase level. It is suggested that the fall in leucocyte ascorbic acid is due to the migration of ascorbic acid laden leucocytes to the site of the infarction and the dilution of the white cell pool by cells which have not yet taken up their ascorbic acid from the plasma. This is in keeping with the finding of higher heart muscle concentrations of ascorbic acid in patients dying a coronary death as compared with patients dying a non-coronary death. These changes appear to be under the influence of the adrenal glands and are a response to traumatic stress.

It is a widely held view that the measurement of leucocyte ascorbic acid reflects more accurately the tissue levels of ascorbic acid than does the ascorbic acid saturation test of Crandon, Lund, and Dill (1940), or the measurement of plasma ascorbic acid (Bartley, Kreb, and O'Brien, 1953). On the basis of this belief, a low leucocyte ascorbic acid level has come to be interpreted in each instance to reflect a state of subclinical scurvy in the absence of the overt disease.

The highest concentration of ascorbic acid in the mammalian body is in the adrenal gland (Knox and Goswami, I96I) and, while there is doubt as to its precise role in steroid metabolism (Kitabchi, 1967), there is an inverse relation between the amount of ascorbic acid in the gland and the increased activity of the gland in states of stress (Booker et al., 1955). An increased output of adrenal steroids also results in an increased white cell count in the peripheral blood (Wintrobe, 196I). In view of these two facts, it seemed important to determine whether in states of 'stress' an alteration in leucocyte ascorbic acid would occur.

This paper reports such a study carried out on patients who were 'stressed' by having sustained an acute myocardial infarction.

Received Io May 1971.

\section{Patients and methods}

Patients Thirty-one patients (26 men and 5 women) who had sustained an acute myocardial infarction were studied. Nine of the patients were seen within 6 hours of the onset of infarction and 22 patients within 6 to 12 hours of the infarction. Thereafter, observations were made when possible at 24 hours, I week, 2 weeks, and approximately I month later. The reason for not grouping together all the infarcts occurring within 24 hours of onset was to see whether changes in leucocyte ascorbic acid were related to the adrenal output of cortisol. It has been shown that after operation or accidental injury the plasma cortisol reaches a peak within 5 to 6 hours of the trauma and returns to basal levels after 8 to Io hours (Symington, 1969).

Leucocyte ascorbic acid was measured by the method of Bessey, Lowry, and Brock (1947) as modified by Denson and Bowers (I96I), which gives a mean normal value (24 observations) of $21 \cdot 4 \mu \mathrm{g} / 10^{8}$ WBC (range $16-36 \mu \mathrm{g} / \mathrm{IO}^{8} \mathrm{WBC}$ ).

Plasma cortisol levels were measured by the method of Mattingly (1962) which gives a mean normal value (40 observations) of $15 \mu \mathrm{g} / 100 \mathrm{ml}$ (range 7-23 $\mu \mathrm{g} / 100 \mathrm{ml}$ ).

Total white blood cells counts were performed by a Coulter Counter, normal range $4-10,000 / \mathrm{mm}^{3}$.

Serum aspartate aminotransferase was estimated by the Technicon Autoanalyzer H-25b method 
and reported as Karmen Units per $\mathrm{ml}$ serum, which gives a mean normal value (I00 observations) of $24 \mathrm{KU} / \mathrm{ml}$ serum (range $8-40 \mathrm{KU} / \mathrm{ml}$ serum).

Diet histories Estimation of ascorbic acid content of the diet was based on the tables of McCance and Widdowson (1960).

Necropsy material Abscorbic acid was estimated in samples of heart muscle taken from the left ventricle at necropsy on patients dying from acute myocardial infarction (I0 men, 7 women) with a mean age of $67 \cdot I \pm 9 \cdot 4$ years and compared

- with the ascorbic acid content of heart muscle obtained from patients dying from causes other than heart disease ( 19 men, 7 women) with a mean age of $57.2 \pm 12.6$ years. The time elapsing between the patient's death and the ascorbic acid estimation for the infarction group and the noninfarction group was 33 hours (range 4-68 hours) and 3I hours (range 6-74 hours), respectively.

- Approximately $5 \mathrm{~g}$ wet heart muscle were used in the estimations. Tissue extracts were made by a modification of the method of Sayers, Sayers, and Woodbury (1948), using a 5 per cent instead of a 4 per cent trichloracetic acid solution as the extraction medium and a Kenwood mixer to homogenize the sample. Ascorbic acid estimations were made on aliquots of the filtrate by a modifica-

- tion of the method of Bessey et al. (1947) (Denson and Bowers, I96r), which measures total ascorbic acid (reduced and dehydro ascorbic acid) and expressed as $\mu \mathrm{g}$ per $\mathrm{g}$ tissue.

\section{Results}

Leucocyte ascorbic acid (Table; Fig. I).

- The mean leucocyte ascorbic acid in the 9 patients seen within 6 hours of infarction was $15.4 \mu \mathrm{g} / \mathrm{IO}^{8} \mathrm{WBC}(\mathrm{SD} \pm 6.2)$ which is just below the normal range ( $16-36 \mu \mathrm{g} / \mathrm{IO}^{8} \mathrm{WBC}$ ), while in those ( 22 patients) seen between 6 and 12 hours after infarction the mean level was $8.5 \mu \mathrm{g} / \mathrm{IO}^{8} \mathrm{WBC}(\mathrm{SD} \pm 2 \cdot 3)$. This fall in leucocyte ascorbic acid is highly statistically significant $(P<0.0005)$. Twenty-four hours

- after the infarction (I5 patients), the level had risen a little to a mean of $10 \cdot 2 \mu \mathrm{g} / 10^{8} \mathrm{WBC}$ $(S D \pm 3 \cdot 3)$ which was still significantly less than the initial level of $15.4 \mu \mathrm{g} / \mathrm{IO}^{8}$ WBC $(\mathbf{P}<0.05)$. One week later (20 patients) the mean level was $14.0 \mu \mathrm{g} / \mathrm{IO}^{8} \mathrm{WBC}(\mathrm{SD} \pm 5 \cdot 2)$ which was not significantly different from the - initial level of $15.4 \mu \mathrm{g} / \mathrm{ro}^{8} \mathrm{WBC}$ but is still just below the normal range. Two weeks after the infarction ( 17 patients), the mean leucocyte ascorbic acid level was $15.5 \mu \mathrm{g} / \mathrm{IO}^{8}$ WBC $(S D \pm 4.8)$ which is not significantly different from the level at one week. However, one month after infarction (I4 patients), the mead level was $20.3 \mu \mathrm{g} / \mathrm{IO}^{8} \mathrm{WBC}$ (SD \pm 8.9 ) which is within the normal range.

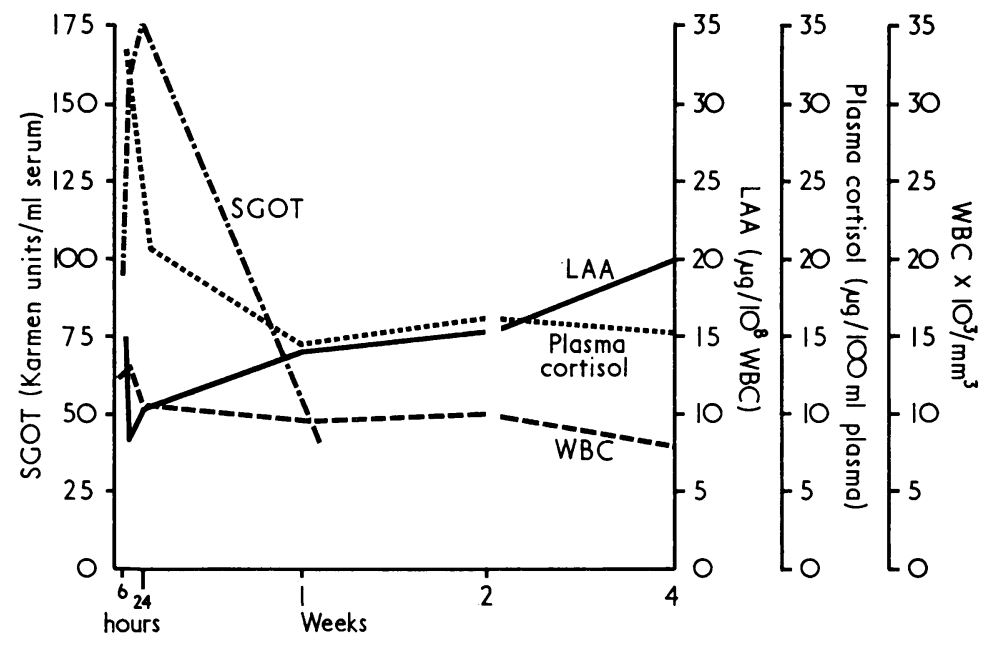

FIG. I The mean changes in leucocyte ascorbic acid plasma cortisol, white blood cell count (WBC), and serum aspartate aminotransferase (SGOT) after acute myocardial infarction are shown.

Since the number of observations at each interval of time is not the same, and to exclude the possibility that the fluctuations are due to random variations within the groups, 5 patients who had had observations made within 6 hours of infarction, 24 hours, and I week, and 5 patients who had had observations made within 6 to 12 hours, 24 hours, and I week have been analysed separately. For the first group of 5 patients the following results were obtained. The mean level at 6 hours was $17.7 \mu \mathrm{g} / 10^{8} \mathrm{WBC}(\mathrm{SD} \pm 6 \cdot 2)$, at 24 hours was $10 \cdot 8 \mu \mathrm{g} / \mathrm{IO}^{8} \mathrm{WBC}(\mathrm{SD} \pm \mathrm{I} \cdot 8)$,

TABLE Composite data showing means with I SD

\begin{tabular}{|c|c|c|c|c|c|c|}
\hline & \multicolumn{6}{|c|}{ Time after infarction } \\
\hline & $\begin{array}{l}0-6 h r \\
\mathrm{~N}=9\end{array}$ & $\begin{array}{l}6-12 h r \\
\mathrm{~N}=22\end{array}$ & $\begin{array}{l}24 h r \\
\mathrm{~N}=15\end{array}$ & $\begin{array}{l}I w k \\
\mathrm{~N}=\mathbf{2 0}\end{array}$ & $\begin{array}{l}2 w k \\
\mathrm{~N}=17\end{array}$ & $\begin{array}{l}I m t h \\
\mathrm{~N}=\mathrm{I} 4\end{array}$ \\
\hline $\begin{array}{l}\text { Leucocyte ascorbic acid } \\
\left(\mu \mathrm{g} / \mathrm{IO}^{8} \text { WBC }\right)\end{array}$ & $\begin{array}{r}15 \cdot 4 \\
\pm 6 \cdot 2\end{array}$ & $\begin{array}{r}8.5 \\
+2.3\end{array}$ & $\begin{array}{r}10 \cdot 2 \\
\pm 3 \cdot 3\end{array}$ & $\begin{array}{r}14 \cdot 0 \\
\pm 5 \cdot 2\end{array}$ & $\begin{array}{r}15.5 \\
\pm 4.8\end{array}$ & $\begin{array}{r}20 \cdot 3 \\
\pm 8.9\end{array}$ \\
\hline $\begin{array}{l}\text { Plasma cortisol } \\
(\mu \mathrm{g} / \mathrm{r} 00 \mathrm{ml} \text { plasma })\end{array}$ & $\begin{array}{r}N=7 \\
32.9 \\
\pm 9.9\end{array}$ & $\begin{array}{r}N=I 4 \\
33.4 \\
\pm 22.5\end{array}$ & $\begin{array}{r}N=15 \\
20.7 \\
\pm 9.1\end{array}$ & $\begin{array}{r}N=12 \\
14.8 \\
\pm 4.9\end{array}$ & $\begin{array}{r}N=7 \\
16 \cdot 1 \\
\pm 8.9\end{array}$ & $\begin{array}{r}N=7 \\
15.3 \\
\pm 4.0\end{array}$ \\
\hline $\begin{array}{l}\text { WBC } \\
\times 10^{3} / \mathrm{mm}^{3}\end{array}$ & $\begin{array}{r}N=7 \\
12.3 \\
\pm 6.5\end{array}$ & $\begin{array}{r}N=21 \\
13.3 \\
\pm 5.4\end{array}$ & $\begin{array}{r}N=13 \\
10.9 \\
\pm 2.7\end{array}$ & $\begin{array}{r}N=17 \\
9.7 \\
\pm 3.5\end{array}$ & $\begin{array}{r}N=I 3 \\
10.1 \\
\pm 2.9\end{array}$ & $\begin{array}{r}\mathrm{N}=7 \\
7.7 \\
\pm 2.5\end{array}$ \\
\hline $\begin{array}{l}\text { Serum aspartate amino- } \\
\text { transferase }\end{array}$ & $\begin{array}{r}N=10 \\
95 \cdot 7\end{array}$ & $\begin{array}{r}N=21 \\
162 \cdot 2\end{array}$ & $\begin{array}{l}N=21 \\
184 \cdot 6\end{array}$ & $\begin{array}{r}N=18 \\
4 I \cdot I\end{array}$ & & \\
\hline (Karmen units/ml serum) & \pm 93.9 & $\pm 32 \cdot 2$ & $\pm 103 \cdot 8$ & $\pm 24 \cdot 0$ & & \\
\hline
\end{tabular}




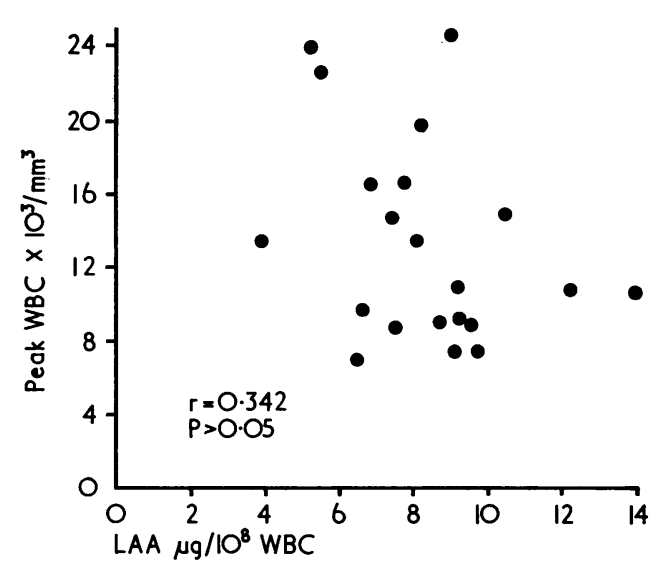

FIG. 2 Relation between the peak white blood cell count (WBC) and the leucocyte ascorbic acid ( $L A A)$.

and at I week I8.I $\mu \mathrm{g} / \mathrm{IO}^{8} \mathrm{WBC}(\mathrm{SD} \pm 3 \cdot 0$ ), while for the second group, the mean figures were $9.7 \mu \mathrm{g} / \mathrm{IO}^{8} \mathrm{WBC}(\mathrm{SD} \pm \mathrm{I} \cdot 5)$ at 6 to $\mathrm{I2}$ hours, $10.5 \mu \mathrm{g} / 10^{8} \mathrm{WBC}(\mathrm{SD} \pm 2.8)$ at 24 hours, and $17 \cdot 1 \mu \mathrm{g} / 10^{8} \mathrm{WBC}(\mathrm{SD} \pm 2 \cdot 7)$ at I week. These means and fluctuations are similar to the group as a whole.

Relation between leucocyte ascorbic acid and peak WBC count There were $2 \mathrm{I}$ observations for analysis (Fig. 2). There was no statistically significant relation between the height of the WBC count and the leucocyte ascorbic acid level made on the same sample of blood ( $r=0.342 ; P>0.05)$.

Relation between leucocyte ascorbic acid 2 weeks after infarction and peak SGOT level There were 15 observations available for analysis (Fig. 3). It was noted that the higher the peak serum aspartate aminotransferase level after the infarction, the lower the leuco-

FIG. 3 Relation between the peak serum aspartate aminotransferase (SGOT) and leucocyte ascorbic acid ( $L A A)$ measured two weeks after infarction.

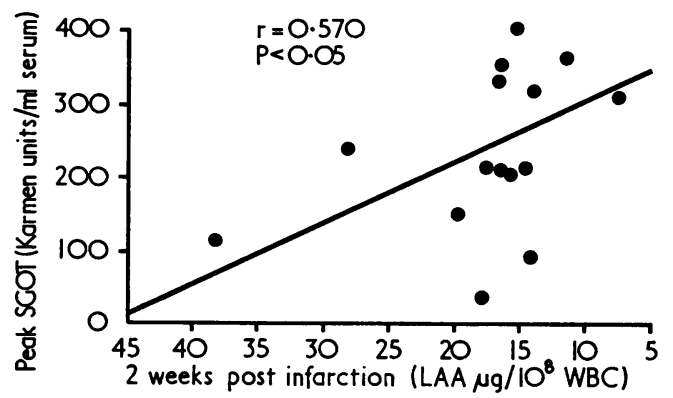

cyte ascorbic acid 2 weeks after infarction. This was statistically significant at the 5 per cent level $(r=0.57 ; P<0.05)$.

Plasma cortisol levels (Table I; Fig. I) The mean plasma cortisol level in the 7 patients seen within 6 hours of infarction was $32.9 \pm 9.9 \mu \mathrm{g} / 100 \mathrm{ml}$ plasma which is well above the normal range $(7-23 \mu \mathrm{g} / 100 \mathrm{ml}$ plasma). In those ( 14 patients) seen within 6 to 12 hours of infarction, the mean level had not significantly changed $(33.4 \pm 22.5 \mu \mathrm{g} / 100$ $\mathrm{ml}$ plasma) though there was a much wider scatter of results. Twenty-four hours after the infarction (I5 patients) the plasma cortisol level had fallen to a mean of $20.7 \pm$ $9 . \mathrm{I} \mu \mathrm{g} / \mathrm{I} 00 \mathrm{ml}$ plasma, and by I week ( 12 patients) had returned to normal (I4.8 \pm $4.9 \mu \mathrm{g} / 100 \mathrm{ml}$ plasma) and thereafter remained normal.

Relation between peak plasma cortisol level and peak SGOT level There were 18 observations available for analysis (Fig. 4). It was observed that the higher the SGOT level after the infarction the higher the plasma cortisol level. This was statistically significant at the 5 per cent level $(r=0.4742 ; P<0.05)$.

Relation between plasma cortisol level and peak WBC count There were 12 observations available for analysis (Fig. 5). It was observed that though there was a trend for the higher plasma cortisol levels to be associated with the higher WBC counts, this just failed to reach statistical significance $(r=0.556 ; P>$ $0.05>0.1$ ).

Serum aspartate aminotransferase levels (Table I; Fig. I). Though the mean levels were significantly raised within 6 hours and I2 hours of infarction, being $95.7 \pm 93.9$ $\mathrm{KU} / \mathrm{ml}$ and $162 \cdot 2 \pm 32 \cdot 2 \mathrm{KU} / \mathrm{ml}$, respectively,

FIG. 4 Relation between the peak serum aspartate aminotransferase (SGOT) and peak plasma cortisol level.

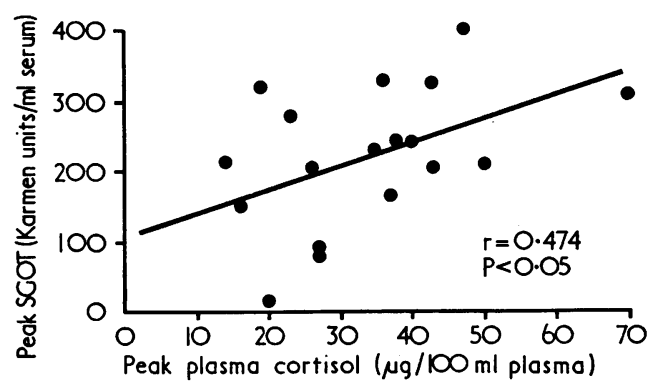




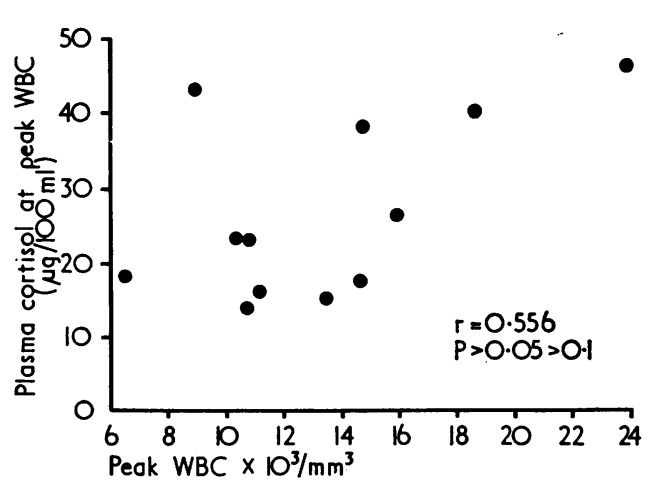

FIG. 5 Relation between plasma cortisol level and the white blood cell count (WBC) at the peak WBC.

the peak serum aspartate aminotransferase level occurred 24 hours after infarction, the mean being $184.6 \pm 103.8 \mathrm{KU} / \mathrm{ml}$. Within one week the mean level had returned to nearly normal, being $4 \mathrm{I} \cdot \mathrm{I} \pm 24 \cdot 0 \mathrm{KU} / \mathrm{ml}$.

Relation between leucocyte ascorbic acid and peak plasma cortisol level There were 14 observations available for analysis. No statistically significant relation was established between the peak plasma cortisol level and the leucocyte ascorbic acid measured at the same time $(r=0.106 ; P>0.05)$.

White blood cell count (WBC) (Table I; Fig. I). The mean WBC count in the 7 patients seen within 6 hours of the infarction was $12.3 \pm 6.5 \times 10^{3} / \mathrm{mm}^{3}$, reaching a peak of $13.3 \pm 5.4 \times 10^{3} / \mathrm{mm}^{3}$ in those (21 patients) seen between 6 hours and 12 hours after infarction. Twenty-four hours after infarction (13 patients) the mean WBC count had fallen to $10.9 \pm 2.7 \times 10^{3} / \mathrm{mm}^{3}$. The mean WBC count remained around this high normal for the next 2 weeks, the levels at I week (17 patients) and 2 weeks ( 13 patients) being $9.7 \pm 3.5 \times 10^{3} / \mathrm{mm}^{3}$ and $10.1 \pm 2.9 \times 10^{3} / \mathrm{mm}^{3}$, respectively. One month after the infarction (7 patients) the mean WBC count had returned to normal $\left(7.7 \pm 2.5 \times 10^{3} / \mathrm{mm}^{3}\right)$.

Relation between ascorbic acid content of myocardial muscle from patients dying coronary death and from those dying non-coronary death There were 17 samples of heart muscle from patients dying a coronary death and 26 samples from patients dying a non-coronary death for comparison. The mean ascorbic acid concentration in the heart muscle of the coronary deaths was $47 \cdot 9 \pm 26 \cdot 7 \mu \mathrm{g} / \mathrm{g}$ as compared to a mean of $35.7 \pm 19.2 \mu \mathrm{g} / \mathrm{g}$. This difference is statistically significant at the 5 per cent level $(t=I \cdot 74) P<0.05)$.

\section{Discussion}

After an acute myocardial infarction the leucocyte ascorbic acid (LAA) falls irrespective of the severity of the episode to levels $\left(8.5 \pm 2.3 \mu \mathrm{g} / 10^{8} \mathrm{WBC}\right)$ that are in the scorbutic range, and remains, in general, lower than normal (> I6 LAA $\mu \mathrm{g} / \mathrm{IO}^{8} \mathrm{WBC}$ ) during the next two weeks (Fig. I). The interpretation of the leucocyte ascorbic level, therefore, in stressful situations involving tissue trauma at least, requires careful consideration before attributing the low levels to subclinical scurvy. The peak fall in the level after an acute myocardial infarction occurs at the peak WBC count, namely 6 to I2 hours after the incident. However, since there is no statistical correlation between the leucocyte ascorbic acid level and the WBC level at this time $(P>0.05)$, this suggests that the low leucocyte ascorbic acid is not simply a dilution phenomenon. A possible explanation is that the WBC, which appear as a response to the traumatic event, have a low leucocyte ascorbic acid content and that the circulating population of WBC with a normal content of leucocyte ascorbic acid have left the circulation. The observation that the infarcted hearts, at necropsy, have a higher tissue content of ascorbic acid than the noninfarcted hearts is in keeping with this view, namely that the WBC migrate to the infarcted muscle carrying their complement of ascorbic acid probably for healing purposes and the 'new' WBC enter the circulation and take up ascorbic acid from the serum. Both these events, a sharp fall in leucocyte ascorbic acid and a rise in WBC count, occur at the time of maximum adrenal stimulation as reflected by the peak plasma cortisol level. In view of the direct relation between increased adrenal function and an increased WBC (Wintrobe, 196I) and the inverse relation between increased adrenal function and its ascorbic acid content (Booker et al., I955), it is likely that changes in both the WBC and leucocyte ascorbic acid are under the influence of the adrenal glands and are a response to 'stress'.

Analysis also shows that the larger the myocardial infarction as reflected by the serum aspartate aminotransferase level (Nydick, Wroblewski, and LaDue, 1955; Rudolph, Dutton, and Schaefer, 1955; Lemley-Stone et al., 1955) the higher the rise in plasma cortisol $(\mathrm{P}<0.05)$ and the greater the adrenocortical activity the higher the WBC level (Bailey, Abernethy, and Beaven, 1967), though the 
relation between the plasma cortisol level and WBC count just failed to reach statistical levels in the present study $(r=0.556)$. After this acute phase of adrenal activity, which lasts between $I$ to 7 days, the leucocyte ascorbic acid rises slowly over the next 2 weeks, eventually reaching normal levels I month after infarction (Fig. I). The WBC count remains around a high normal of $10,000 / \mathrm{mm}^{3}$ for at least 2 weeks after infarction. The explanation for these two observations is suggested by the histopathology of a resolving myocardial infarction. White cell infiltration of the infarcted muscle reaches a peak within 4 days and thereafter the WBCs slowly disintegrate and are completely gone from the infarcted muscle by the 14th day (Lannigan, 1966). Therefore, the low leucocyte ascorbic acid for the 2 weeks after infarction is probably a reflection of this healing process, and is due to the deviation of ascorbic acid-laden leucocytes from the circulation to the heart muscle. Thereafter healing by fibrous scar formation takes place.

It is unlikely that any of the changes described reflects previous ascorbic acid malnutrition. Diet histories from a random sample of 16 of the patients revealed a mean daily intake of ascorbic acid of $52.7 \mathrm{mg}$ per day $(\mathrm{SD} \pm 25.3)$ and it is calculated that $10 \mathrm{mg}$ per day of ascorbic acid is enough to prevent scurvy (Bartley et al., 1953). Furthermore, the maximum fall in leucocyte ascorbic acid did not relate to the ascorbic acid intake of the patient, but in view of the possible relation between deficiency of ascorbic acid and the development of atherosclerosis (Shaffer, 1970), it is noteworthy that the mean intake of the group is much less than that (70 mg per day) recommended by the United States Nutritional Research Council (I963).

It has been claimed that the serum ascorbic acid is higher in women than men of the same age group (Morgan, Gillum, and Williams, 1955; Dodds, 1969) and that the difference is not due to smoking habits, though chronic smoking also is said to reduce both serum ascorbic acid and leucocyte ascorbic acid (Pelletier, 1968; Brook and Grimshaw, 1968). Guinea-pigs rendered ascorbutic by diet develop arterial lesions morphologically typical of atherosclerosis (Willis, 1953; Ginter, Babala, and Cerven, 1969), and these lesions are reversible on feeding ascorbic acid (Willis, 1957). Ascorbic acid is also reported to retard the development of hypercholesterolaemia in cholesterol-fed rabbits (McConnell and Sokoloff, 1964; Myasnikov, 1958) and to retard the development of atheromatous changes in their aortas (Myasnikov, 1958). Ascorbic acid fed to 20 atherosclerotic persons with hypercholesterolaemia reduced the cholesterol level by 30 per cent (McConnell and Sokoloff, 1964), while ascorbic acid fed to 66 healthy Bantu men had no influence on the serum cholesterol level (Bronte-Stewart, Roberts, and Wells, 1963). Ginter (I968) reports a negative correlation between serum ascorbic acid and serum cholesterol in population studies from Eastern Europe.

Atherosclerosis is said to develop in arteries at sites of mechanical stress (Texon, 1957). A study of human arterial tissue at necropsy has revealed localized depletion of ascorbic acid at these sites, adjacent segments of the arteries having a higher content of ascorbic acid, and there was some evidence to suggest that it was possible to replenish the ascorbic acid in the arteries by ascorbic acid therapy (Willis and Fishman, 1955). Further evidence that ascorbic acid may have a direct influence in coronary artery disease is suggested by the reversion of abnormalities in the electrocardiogram in two cases of scurvy after the administration of ascorbic acid (Shafar, 1967) and the prevention of electrocardiographic changes due to digitalis therapy by ascorbic acid (Schultheiss and Tarai, 1959), at least under some circumstances (Seymour and Sowton, 1964). Finally, dogs in which myocardial infarction was produced experimentally, showed a 122 per cent increase in protein synthesis in the centre of the infarcted area as compared with controls when treated with ascorbic acid (Gudbjarnason et al., 1966).

The accumulated evidence, including the observations in the present paper, suggests that the role of ascorbic acid, both in the development of atherosclerosis and in the management of acute myocardial infarction, requires further study.

\section{References}

Bailey, R. R. Abernethy, M. H., and Beaven, D. W. (1967). Adrenocortical response to the stress of an acute myocardial infarction. Lancet, $\mathbf{I}, 970$.

Bartley, W., Kreb, H. A., and O'Brien, J. R. P. (1953). Vitamin $\mathrm{C}$ requirement of human adults. Medical Research Council. Special Report Series, No. 280.

Bessey, O. A., Lowry, O. H., and Brock, M. J. (1947). The quantitative determination of ascorbic acid in small amounts of white blood cells and platelets. fournal of Biological Chemistry, 168, 197.

Booker, W. M., DaCosta, F. M., Tureman, J. R., Froix, C., and Jones, W. (1955). The relation of ascorbic acid to adrenocortical function during cold stress. Endocrinology, 56, 413.

Bronte-Stewart, B., Roberts, B., and Wells, V. M. (1963). Serum cholesterol in vitamin C deficiency in man. British fournal of Nutrition, 17, 61. 
Brook, M., and Grimshaw, J. J. (1968). Vitamin C concentration of plasma and leukocytes as related to smoking habit, age, and sex of humans. American Fournal of Clinical Nutrition, $21,1254$.

Crandon, J. H., Lund, C. C., and Dill, D. B. (1940). Experimental human scurvy. New England fournal of Medicine, 223, 353.

Denson, K. W., and Bowers, E. F. (I96I). The determination of ascorbic acid in white blood cells. A comparison of WBC ascorbic acid and phenolic acid excretion in elderly patients. Clinical Science, 21, 157.

Dodds, M. L. (1969). Sex as a factor in blood levels of ascorbic acid. Fournal of the American Dietetic Association, 54, 32.

Ginter, E. (1968). The influence of chronic hypovitaminosis $\mathrm{C}$ on cholesterol metabolism and arterial sclerosis. Ceskoslovenská Fysiologie, 17, 423.

Ginter, E., Babala, J., and Cerven, J. (1969). The effect of chronic hypovitaminosis $\mathrm{C}$ on the metabolism of cholesterol and atherogenesis in Guinea pigs. fournal of Atherosclerosis Research, 10, 34I.

Gudbjarnason, S., Fenton, J. C., Wolf, P. L., and Bing, R. J. (1966). Stimulation of reparative processes following experimental myocardial infarction. Archives of Internal Medicine, 118, 33.

Kitabchi, A. E. (1967). Ascorbic acid in steroidogenesis. Nature (London), 215, 1385.

Knox, W. E., and Goswami, M. N. D. (196I). Ascorbic acid in man and animals. In Advances in Clinical Chemistry, Vol. 4, p. 121. Ed. by $\mathrm{H}$. Sobotka and C. P. Stewart. Academic Press, New York and London.

Lannigan, R. (1966). Cardiac Pathology, p. 232. Butterworth, London.

Lemley-Stone, J., Merrill, J. M., Grace, J. T., and Meneely, G. R. (1955). Transaminase in experimental myocardial infarction. American fournal of Physiology, 183, 555 .

McCance, R. A., and Widdowson, E. M. (1960). The composition of foods. Medical Research Council. Special Report Series, No. 297.

McConnell, B., and Sokoloff, B. (1964). The effect of ascorbic acid on the blood cholesterol and clearing factor levels: experimental and clinical study. In Proceedings of the 6th International Congress of Nutrition, Edinburgh, 1963, p. 548. Livingstone, Edinburgh.

Mattingly, D. (1962). A simple fluorimetric method for the estimation of free II-hydroxycorticoids in human plasma. Fournal of Clinical Pathology, 15, 374.

Morgan, A. F., Gillum, H. L., and Williams, R. I. (1955). Nutritional status of the aging. 3. Serum ascorbic acid and intake. Fournal of Nutrition, 55, 43 I.
Myasnikov, A. L. (1958). Influence of some factors on development of experimental cholesterol atherosclerosis. Circulation, 17, 99.

Nydick, I., Wroblewski, F., and LaDue, J. S. (1955). Evidence for increased serum glutamic-oxalacetic transaminase activity following graded myocardial infarcts in dogs. Circulation, 12, 161.

Pelletier, O. (I968). Smoking and vitamin C levels in humans. American fournal of Clinical Nutrition, 21, 1259.

Rudolph, L. A., Dutton, R., and Schaefer, J. A. (1955). Glutamic-oxalacetic transaminase levels in experimental tissue damage. Fournal of Clinical Investigation, 34, 960.

Sayers, M. A., Sayers, G., and Woodbury, L. A. (1948). The assay of adrenocorticotrophic hormone by the adrenal ascorbic acid-depletion method. Endocrinology, 42, 379.

Schultheiss, E., and Tarai, J. (1959). Zur Beeinflussung von digitalisbedingten Nibenwirkungen mit Askorbinsäure beim Altersherzen. Zeitschrift für die gesamte innere Medizin und ihre Grenzgebiete, $14,267$.

Seymour, J., and Sowton, E. (1964). Action of ascorbic acid on digitalis effects in the cardiogram. British Medical fournal, 1, 1551 .

Shafar, J. (1967). Rapid revision of electrocardiographic abnormalities after treatment of two cases of scurvy. Lancet, 2, 176.

Shaffer, C. F. (1970). Ascorbic acid and atherosclerosis. American fournal of Clinical Nutrition, 23, 27.

Symington, T. (1969). Functional Pathology of the Human Adrenal Gland, p. 502. E. \& S. Livingstone, Edinburgh and London.

Texon, M. (1957). A hemodynamic concept of atherosclerosis, with particular reference to coronary occlusion. Archives of Internal Medicine, 99, 418.

United States Nutritional Research Council (1963). (Cited by Office of Health Economics (196 Malnutrition in the 1960s. No. 23. London.)

Willis, G. C. (1953). An experimental study of the intimal ground substance in atherosclerosis. Canadian Medical Association fournal, 69, 17.

Willis, G. C. (1957). The reversibility of atherosclerosis. Canadian Medical Association fournal, 77, 106.

Willis, G. C., and Fishman, S. (1955). Ascorbic acid content of human arterial tissue. Canadian Medical Association fournal, 72, 500.

Wintrobe, M. M. (1961). Clinical Hematology, p. 49. Henry Kimpton, London.

Requests for reprints to Dr. Robert Hume, Medical Unit, Southern General Hospital, Glasgow S.W.I. 